\title{
Regrowth and biofouling in two species of cultivated kelp in the Shetland Islands, UK
}

\author{
Christine Rolin $^{1}$ (D) $\cdot$ Rhiannon Inkster $^{1} \cdot$ Josh Laing $^{1} \cdot$ Lesley McEvoy $^{1}$
}

Received: 12 August 2016/Revised and accepted: 8 February 2017 / Published online: 6 March 2017

(C) The Author(s) 2017. This article is published with open access at Springerlink.com

\begin{abstract}
The meristem of the kelps Laminaria digitata and Saccharina latissima is located at the base of the blade, growth can therefore continue when the distal blade is lost due to erosion or harvesting. The aim of the study was to determine the regrowth potential of cultivated kelp in the Shetland Islands (UK) to assess feasibility of harvesting twice in one growing season. Laminaria digitata and S. latissima grown on longlines at sea were sampled between March and August, and harvested either at the stipe (whole) or $10 \mathrm{~cm}$ above the stipe-blade transition zone (partial) May-August. Image analysis was used to estimate blade length, width, area and fouled area. $S$. latissima increased in length more than L. digitata between March and August, and in August, while whole $S$. latissima experienced a net loss in length, partially cut blades had a net increase. Whole blades significantly increased in length for both species but only partially cut S. latissima significantly regrew. In late summer, severe biofouling by tunicates made up 12 and $27 \%$ of the biomass at two sites. Interestingly, S. latissima was less fouled than L. digitata. Consequently, S. latissima shows the greatest potential for the application of partial cutting to improve cultivated biomass yields. However, the period for regrowth is limited by low yields in early spring and blade degradation in late summer. In order to optimise biomass yields, further understanding is needed on the abiotic and biotic factors that control growth and biofouling on natural and farmed seaweed.
\end{abstract}

Christine Rolin

c.rolin.09@aberdeen.ac.uk

1 NAFC Marine Centre, University of Highlands and Islands, Port Arthur, Scalloway, Shetland Islands ZE1 OUN, UK
Keywords Laminaria digitata $\cdot$ Saccharina latissima . Phaeophyceae $\cdot$ Macroalgae $\cdot$ Meristem $\cdot$ Partial cutting . Epiphytes

\section{Introduction}

The kelps Laminaria digitata (Hudson) J.V. Lamouroux and Saccharina latissima (Linnaeus) C.E. Lane, C. Mayes, Druehl, and G.W. Saunders are large, fast-growing flora that dominate the sublittoral in the North East Atlantic (Bartsch et al. 2008). Kelps are harvested from wild populations by hand or by mechanical harvesters for their alginates (Christie et al. 1998; Mclaughlin et al. 2006; Guiry and Morrison 2013) and increasingly for their use in food and biofuel production (Kraan 2013; Kerrison et al. 2015).

Scaling up wild kelp harvesting could have detrimental impacts on ecosystems; therefore, focus has shifted to cultivating kelp in marine aquaculture. Cultivation techniques for on-growing at sea have been developed for a number of Atlantic seaweed species such as L. digitata, S. latissima, Alaria esculenta (Linnaeus) Greville, Undaria pinnatifida (Harvey) Suringar and Palmaria palmata (Linnaeus) F. Weber \& D. Mohr (Edwards and Dring 2011; Edwards et al. 2011; Handå et al. 2013; Peteiro and Freire 2013, 2014). Cultivated seaweed can be grown on spools and transferred to longlines or droppers, or can be directly grown on nets and textiles. At present, optimisation of growing and harvesting techniques is needed to improve cost-effectiveness of seaweed farming.

The kelps $L$. digitata and S. latissima, like many other species of kelp, undergo seasonal patterns of rapid length growth in spring/early summer followed by decay in late summer/autumn (e.g. Parke 1948; Kain 1979; Bartsch et al. 2008; Saunders and Metaxas 2008; Andersen et al. 2011; 
Krumhansl and Scheibling 2011; Nielsen et al. 2014). New tissue is formed in the meristem located at the base of the blade. Blade growth can be attributed to current photosynthesis in the basal blade and translocation of photosynthates from the mature blade (Schmitz and Lobban 1976; Bartsch et al. 2008). Growth rates vary across seasons, latitudes and species, and may be influenced by a number of factors from environmental conditions to life stage and blade size (e.g. Henley and Dunton 1995; Bartsch et al. 2008; Zhang et al. 2012; Kerrison et al. 2015)

Cutting the blade above the meristem may allow regrowth of the blade, potentially facilitating recovery in wild harvested kelp beds and increasing yields in farmed kelp. In South Africa, wild populations of Ecklonia maxima (Osbeck) Papenfuss are traditionally harvested by cutting below the meristem at the stipe; however, yields per harvest area can be increased by cutting the fronds $20-30 \mathrm{~cm}$ above the base of the primary blade (Levitt et al. 2002). In northern Japan, thinning of cultivated $U$. pinnatifida improved yields of highquality sporophytes before the start of the traditional harvest season, and these sporophytes fetch higher prices due to their taste and texture (Gao et al. 2014). In Norway, mechanical harvesting of Laminaria hyperborea (Gunnerus) Foslie is managed by allowing 5 years between harvests in each area; the harvesting method only removes the large canopy plants and the kelp forest recovers as sub-canopy recruits grow to form the new canopy (Christie et al. 1998; Vea and Ask 2011).

A number of studies have shown species of Saccharina spp. and Laminaria spp. degrade in late summer due to blade breakage and erosion in both wild and farmed kelp populations (Saunders and Metaxas 2008; Andersen et al. 2011; Park and Hwang 2012; Zhang et al. 2012; Peteiro and Freire 2013; Førde et al. 2016). Increasing temperatures may lead to earlier and larger outbreaks of biofouling organisms such as bryozoans which accelerate decay and breakage (Saunders and Metaxas 2008; Scheibling and Gagnon 2009; Park and Hwang 2012). Severe biofouling reduces the value of kelp harvests as they cannot be used for human consumption. Management options for biofouling include shortening the harvest season, placing farms in more exposed sites or alternatively using the algal biomass in lower quality products (Park and Hwang 2012; Peteiro and Freire 2013; Førde et al. 2016). To summarise, the size of individual blades is determined both by new tissue growth and loss through breakage and erosion; on balance the relative contribution of each force changes through the year leading to periods of net gain or loss in blade length.

The aim of this study was to assess the potential for harvesting line-grown kelp twice in one growing season in the Shetland Islands by allowing kelp to regrow between the first and second harvest by (1) determining the changes in length, width and yield of $L$. digitata and S. latissima between May and August and (2) estimating the percentage area fouled of L. digitata and S. latissima.

\section{Materials and methods}

\section{Sea cultivation trials in the Shetland Islands (UK)}

Mature reproductive material (sori) of $L$. digitata was collected from the shore in Scalloway, Shetland Islands $\left[60^{\circ} 07.57^{\prime}\right.$ $\mathrm{N}, 001^{\circ} 17.22^{\prime} \mathrm{W}$ (WGS84)], in July 2014. Reproductive material was hand-collected at low tide by cutting the distal blade where darkened sori were visible and clear of epiphytes. The cut pieces of $L$. digitata were stored in seawater in a plastic, insulated 'cooler box' and then immediately transferred to the laboratory for processing. The blades were cleaned and spore release induced through partial dehydration and subsequent re-immersion in seawater according to Edwards et al. (2011).

Flasks and tanks for cultivation were stored in a temperature-controlled room at $11^{\circ} \mathrm{C}$. Seawater $(35 \%$ o salinity) was taken from $5 \mathrm{~m}$ depth in Scalloway, Shetland Islands, filtered to $1 \mu \mathrm{m}$ and sterilised by UV light treatment. The room was cleaned and disinfected weekly.

Spools of string for sporophyte cultivation were prepared using square polyvinyl chloride pipes and wound with $35 \mathrm{~m}$ of 1.3-mm-diameter cross-braided nylon string without core. The string was leached in several changes of warm freshwater over approximately $24 \mathrm{~h}$ to remove any oils or chemicals.

Two methods were used for cultivation from spores to gametophytes and sporophytes in the hatchery: flask cultivation (Edwards et al. 2011) and direct spore settlement (Flavin et al. 2013).

Flask cultivation Spores were released on 10 July 2014 and cultured in aerated flasks $(n=5)$ under red light at $16-18 \mu \mathrm{mol}$ photons $\mathrm{m}^{-2} \mathrm{~s}^{-1}$ at $10-11{ }^{\circ} \mathrm{C}$ under $12 \mathrm{~h}: 12 \mathrm{~h}$ light/dark cycle. A single 5 f. fluorescent light tube (Osram Warm White+ L58/ $830, \mathrm{DE})$ covered in red cellophane was placed horizontally alongside the culture flasks. Using standard sterile techniques, every 10-14 days the gametophyte cultures were allowed to settle at the bottom of their flasks for a few minutes, without aeration, before the bulk of their seawater medium was discarded, allowing the concentrated culture to be transferred into a new autoclaved flask of seawater. Cell-hi F2P nutrient mix (Varicon Aqua Solutions, UK) was added to the new flask at a concentration of $1 \mathrm{~mL}$ nutrient stock solution per litre of culture solution. The nutrient stock solution was made by dissolving $100 \mathrm{~g}$ Cell-hi F2P nutrient mix in $1 \mathrm{~L}$ of cooled, boiled tap water. In addition, germanium dioxide was added at a concentration of $0.5 \mathrm{~mL}$ of $0.1 \%(w / v)$ stock solution to prevent the growth of diatoms (Lewin 1966; Redmond et al. 2014). The new culture flask was then aerated and illuminated as before.

The biomass of the cultures was allowed to increase in this way until the development of early sporophytes was observed under the microscope and the flasks contained a mixture of 
gametophytes and sporophytes. The seedling cultures were then transferred to seawater tanks on 5 September 2014 by pulse blending the concentrated cultures and spraying them onto spools of string using a small garden spray. The spools were then suspended vertically in two static $660 \mathrm{~L}$ polyethylene tanks $(n=2)$ containing $1 \mu \mathrm{m}$ filtered, UV-treated seawater.

Direct spore settlement Spores were released on 10 September 2014 and immediately transferred to $20 \mathrm{~L} 1 \mu \mathrm{m}$ filtered, UV-treated seawater in plastic containers, yielding a final stocking density of 8000 spores $\mathrm{mL}^{-1}$ (based on a recommended range between 5000 and 10,000 spores $\mathrm{mL}^{-1}$ by Flavin et al. 2013). In addition to adding $20 \mathrm{~mL}$ of Cell-hi F2P nutrient stock solution to each container, $10 \mathrm{~mL}$ of $0.1 \%(w / v)$ stock solution of germanium dioxide stock solution was also added (Lewin 1966; Redmond et al. 2014). Three spools of string were laid on top of glass rods (to raise the string from the bottom) in each container and left in the dark at $11^{\circ} \mathrm{C}$ to allow the zoospores to settle. After $24 \mathrm{~h}$, the spools were carefully transferred into two static 660-L seawater tanks.

Both tanks were kept under a 12:12 h light/dark cycle and water temperature ranged from 10 to $14{ }^{\circ} \mathrm{C}$. The tanks were cleaned and disinfected twice a week with cleaning agent TOPAZ CL1 (ECOLAB, US) $(4.0 \% v / v)$. After rinsing with tap water and seawater, the tanks were re-filled with fresh $1 \mu \mathrm{m}$ filtered, UV-treated seawater to which $35 \mathrm{~g}$ of Cell-hi F2P nutrient powder mix (dissolved in a small volume of tap water) was added. Light intensity was increased from 18 to $70 \mu \mathrm{mol}$ photons $\mathrm{m}^{-2} \mathrm{~s}^{-1}$ by lowering the bank of three double 4-ft. fluorescent light tubes (Osram Cool White+ L36/840, DE) covered in blue cellophane suspended over each tank. Aeration was gradually increased over 2 weeks from static to high with four bubbling air stones disturbing the water surface.

After 2-3 months of cultivation in indoor tanks, the L. digitata sporophytes were transferred onto longlines at $2 \mathrm{~m}$ depth at Sandsound $(2 \times 240 \mathrm{~m})$ and Lea of Trondra $(2 \times 80 \mathrm{~m})$ on 19 November and 5 December 2014, respectively. The sporophytes were transferred to the longlines by feeding the rope through the culture string spool, 4 spools of flask cultivated $L$. digitata at Lea of Trondra, and 12 spools of flask cultivated and 2 spools of directly settled $L$. digitata to Sandsound. As the spool was pulled along the longline, the culture string unwound around the rope and was then secured with splices and knots at both ends.

Saccharina latissima was not cultivated in the hatchery; however, S. latissima settled naturally on the $L$. digitata seeded longlines at average densities of $12.8 \pm 2.6 \%$ or $5.0 \pm 1.3$ individuals per $15 \mathrm{~cm}$ sample $(n=20)$ at Sandsound and $68.8 \pm 4.0 \%$ or $40.0 \pm 3.9$ individuals $(n=21)$ at Lea of Trondra (mean $\pm \mathrm{SE}$ ).
The site at Lea of Trondra $\left(60^{\circ} 06.833^{\prime} \mathrm{N}, 001^{\circ} 16.967^{\prime} \mathrm{W}\right)$ had a depth range of 9-16 $\mathrm{m}$ with longline moorings at 9$12 \mathrm{~m}$ depth. At Lea of Trondra, the longlines consisted of $24 \mathrm{~mm}$ Euroflex sinking rope (W \& J Knox Ltd, UK). A mixture of $100 \mathrm{~kg}$ concrete and fluke anchors were employed while $32 \mathrm{~mm}$ Seasteel 3 strand rope (GaelForce Marine Ltd.) and $32 \mathrm{~mm}$ open link chain (GaelForce Marine Ltd, UK) were used for mooring attachment. The site at Sandsound $\left(60^{\circ}\right.$ $06.833^{\prime} \mathrm{N}, 001^{\circ} 16.967^{\prime} \mathrm{W}$ ) had a depth range of $8-22 \mathrm{~m}$ with a longline mooring grid $5 \mathrm{~m}$ below the water surface. The longlines at Sandsound consisted of $20 \mathrm{~mm}$ 'Seaspun' Staple Spun floating, 'hairy' polypropylene rope (Gael Force Marine Ltd, UK) held in place by a rope grid system consisting of $20 \mathrm{~mm}$ Seasteel rope and fluke anchors. A1 Polyform Buoys (GaelForce Marine Ltd, UK) were attached at regular intervals to the longlines at both sites.

Harvesting, sampling and biomass yield To determine the regrowth and potential increase in yield of both $L$. digitata and $S$. latissima, each species of the line-grown kelp was subjected to different methods of harvesting: (1) whole plants were harvested as a single harvest of whole plants by cutting their stipes, and (2) partially cut plants were harvested twice as a biannual harvest, first the blades were cut approximately $10 \mathrm{~cm}$ above the stipe-blade transition zone, then allowing time for regrowth, they were cut at the stipe for the second harvest. The biannually harvested kelp was subdivided into a further two groups: one first cut in May ('Partial 1') and the other first cut in late June/early July ('Partial 2'). Both these groups had their second harvests in August.

Harvest sections were taken across linear sections of longline of 2 to $10 \mathrm{~m}$ and cut with a handheld knife. Biomass yields were all standardised to kilogram fresh weight per metre of longline and calculated for both sample $(15 \mathrm{~cm})$ and harvest $(2-10 \mathrm{~m})$ sections for both treatments. The biomass was transferred to perforated buckets and wet weighed on the boat using handheld digital luggage scales. Samples of cultivated kelp were taken by cutting $15-\mathrm{cm}$ sections of longline on a monthly basis between March and August 2015. Each sample was stored in a zip-lock bag. Immediately on return to the laboratory, excess liquid was removed and the sample's wet weight was recorded. The samples were then stored up to $48 \mathrm{~h}$ at $4{ }^{\circ} \mathrm{C}$ before all individuals of each sample were laid out flat, along with a visible scale, and an image was taken (Sony Alpha 33 DSLR camera with an 18-55 mm lens) at approximately $2.5 \mathrm{~m}$ height. For the last sampling point in August, the wet weight of tunicates for whole and partially cut kelp was determined by scraping off all tunicates after the image was taken.

Environmental measurements were taken once a month at the time of sampling, a digital thermometer (810-270 Waterresistant Max/Min Thermometer; Electronic Temperature Instruments Ltd, UK) was used to estimate the sea surface 
temperature (SST), irradiance was measured at $2 \mathrm{~m}$ depth with a quantum sensor (Apogee MQ-200, Campbell Scientific Europe) and Secchi disk depth was taken to estimate water clarity.

\section{Growth and biofouling measurements in ImageJ}

Each individual kelp blade in each sample image was numbered using Photofiltre (version 6.53). Blades were not sampled/numbered if clearly broken or $<10 \mathrm{~cm}$ long and whole. Blades that were partially cut and $<10 \mathrm{~cm}$ long were included in the analysis, as we assumed they would have been at least $10 \mathrm{~cm}$ long to have been partially cut. Morphometries of individual blades were measured in ImageJ (version 1.48): length and width were measured using the line tool (at the longest and widest points) and the blade and fouling areas were measured using the outline tool. Each individual kelp species was identified and fouling areas classified into three types: epiphytic algae, bryozoans and tunicates (Fig. 1).

\section{Data analysis}

All data analyses were performed in $\mathrm{R}^{\prime}$ statistical package (version 3.0.2; R Core Team 2013) through RStudio (version 0.99.491; RStudio 2012) and plotted with ggplot2 package (Wickham 2009). Each 15-cm sample or harvest section was considered an independent replicate and each kelp individual within each sample a technical replicate. All data are expressed as mean $\pm \mathrm{SE}$.

Growth in length and width were compared between kelp species and treatments for each site by plotting mean $\pm \mathrm{SE}$ in line plots. The effect of sampling time and site on blade length and width was statistically tested in one- and two-way analysis of variance (ANOVA) for each kelp species. Sampling time combined the two nearest sampling points (one for each site) which were no more than 8 days apart (sampling times-Mar/ Apr $=1$, May $=2, \operatorname{Jun} / \mathrm{Jul}=3$, Aug $=4$, late Aug = 5)
Homogeneity of variance was tested with Bartlett's test. Summary and residuals plots were investigated to check model fit, outliers and large variances. The significance threshold was set at 0.05 . All wet weights were converted to kilograms per metre and yield estimates based on both harvest and sample sections shown in the results. The percentage wet weight made up of biofouling tunicates was only estimated for the last sampling points at each site in August.

The percentage blade area fouled was calculated based on the total area of blades for each species of kelp and type of biofouling and then averaged for each sample. Percentage blade area fouled by the three types fouling organisms was plotted in a box plot for each species at each site across sampling dates as a factor to visualise variation in area fouled and differences between kelp species, sites and biofouling types across the harvest season. Furthermore, total blade area for each species at each site is also represented in a box plot as a frame of reference for total blade area sampled and how total blade area varies between species, sites and months. Blade area only includes one side of the lamina. The biofouling area was not estimated for the partially cut kelp in the present study.

\section{Results}

\section{Environmental measurements}

March to May sea surface temperatures (SST) increased from 7 to $10^{\circ} \mathrm{C}$ at both sites, but, in July and August, at Sandsound were $2{ }^{\circ} \mathrm{C}$ higher than at Lea of Trondra. Irradiance at $2 \mathrm{~m}$ depth ranged from 90 to $230 \mu \mathrm{mol}$ photons $\mathrm{m}^{-2} \mathrm{~s}^{-1}$ at both sites; all sampling days were overcast with no more than interspersed sun. The lowest irradiance was measured at Lea of Trondra on 30 June 2015 and the weather was noted to be particularly cloudy. Water clarity measured by Secchi disk depth ranged from 3.5 to $7.5 \mathrm{~m}$ at Sandsound and 4-6 $\mathrm{m}$ at Lea of Trondra (Table 1).
Fig. 1 a-c The three main types of biofouling found on the cultivated kelp in the Shetland Islands. a Epiphytes on distal tips (e.g. Ectocarpus spp.). b Tunicates (e.g. Ciona intestinalis). c Bryozoans (e.g. Membranipora membranacea) (juvenile Mytilus spp. are also visible on the distal tips). Yellow arrows point to examples of fouling organisms
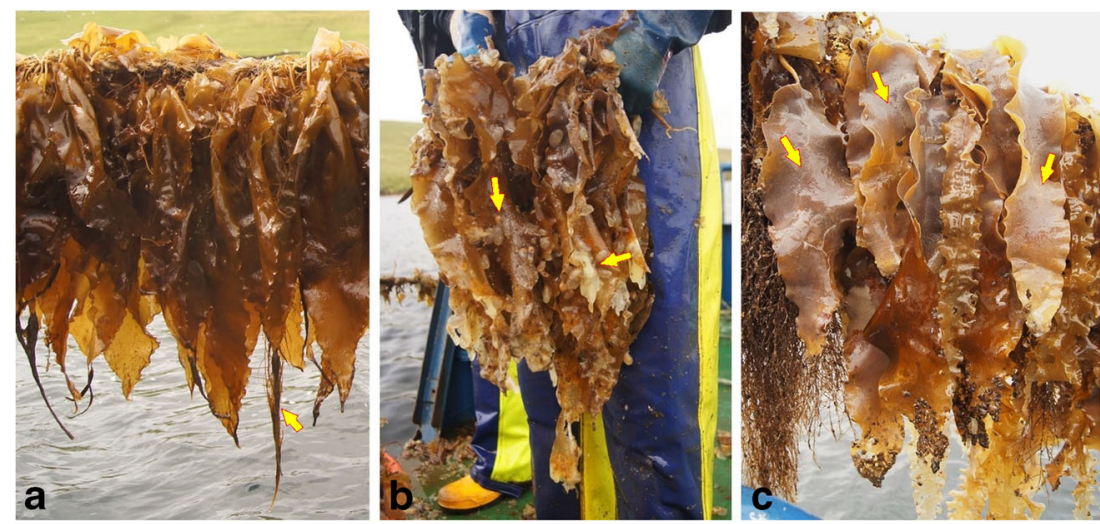
Table 1 Environmental single-point measurements (temperature, irradiance and Secchi disk depth) and estimated sample $(15 \mathrm{~cm})$ and harvest $(2-$ $10 \mathrm{~m}$ ) biomass yields for both sites and treatments

\begin{tabular}{|c|c|c|c|c|c|c|c|c|c|c|c|c|c|}
\hline \multirow[t]{3}{*}{ Site } & \multirow{3}{*}{$\begin{array}{l}\text { Sampling } \\
\text { dates }\end{array}$} & \multirow{3}{*}{$\begin{array}{l}\text { Temperature } \\
\left({ }^{\circ} \mathrm{C}\right)\end{array}$} & \multirow{3}{*}{$\begin{array}{l}\text { Irradiance } \\
(\mu \mathrm{mol} \text { photons } \\
\left.\mathrm{m}^{-2} \mathrm{~s}^{-1}\right)\end{array}$} & \multirow{3}{*}{$\begin{array}{l}\text { Secchi disk } \\
\text { depth }(\mathrm{m})\end{array}$} & \multicolumn{5}{|c|}{ Sample biomass $\left(\mathrm{kg} \mathrm{m}^{-1}\right)$} & \multicolumn{4}{|c|}{ Harvest biomass $\left(\mathrm{kg} \mathrm{m}^{-1}\right)$} \\
\hline & & & & & \multirow[t]{2}{*}{ Whole } & \multirow[t]{2}{*}{$n$} & \multicolumn{2}{|c|}{ Partial cutting } & \multirow[t]{2}{*}{$n$} & \multirow[t]{2}{*}{ Whole } & \multirow[t]{2}{*}{$n$} & \multicolumn{2}{|c|}{ Partial cutting } \\
\hline & & & & & & & 1 & 2 & & & & 1 & 2 \\
\hline \multirow[t]{4}{*}{ Sandsound } & 31.03 .15 & 7.1 & NA & 6 & $0.5 \pm 0.1$ & 5 & & & & & & & \\
\hline & 20.05 .15 & 9.4 & 230 & 3.5 & $2.8 \pm 0.2$ & 6 & $1.1 \pm 0.2$ & & 3 & $2.1 \pm 0.1$ & 3 & $1.4 \pm 0.1$ & \\
\hline & 07.07 .15 & 12.4 & 220 & 4.5 & $3.0 \pm 0.3$ & 5 & $1.5 \pm 0.1$ & $2.9 \pm 0.4$ & 3 & $2.4 \pm 0.4$ & 3 & & $1.8 \pm 0.5$ \\
\hline & 13.08 .15 & 14.1 & 220 & 7.5 & $8.0 \pm 1.7$ & 5 & $4.4 \pm 0.2$ & $4.1 \pm 0.6$ & 3 & $11.6 \pm 1.5$ & 5 & NA & NA \\
\hline \multirow{5}{*}{$\begin{array}{l}\text { Lea of } \\
\text { Trondra }\end{array}$} & 08.04 .15 & 7.0 & 225 & 5 & $0.8 \pm 0.2$ & 4 & & & & & & & \\
\hline & 28.05 .15 & 9.9 & 190 & 5 & $2.5 \pm 0.0$ & 4 & $1.3 \pm 0.2$ & & 2 & $2.5 \pm 0.1$ & 2 & $2.0 \pm 0.5$ & \\
\hline & 30.06 .15 & 10.6 & 90 & 5 & $3.7 \pm 0.5$ & 4 & $1.0 \pm 0.1$ & $1.0 \pm 0.2$ & 2 & $4.2 \pm 1.0$ & 2 & & $2.0 \pm 0.1$ \\
\hline & 07.08 .15 & 12.4 & 230 & 4 & $7.0 \pm 0.9$ & 4 & $4.3 \pm 0.2$ & $3.3 \pm 0.1$ & 2 & $7.3 \pm 0.4$ & 4 & & \\
\hline & 31.08 .15 & 12.7 & 210 & 6 & $15.5 \pm 3.7$ & 4 & $5.4 \pm 1.6$ & $2.6 \pm 0.3$ & 2 & $9.0 \pm 0.3$ & 4 & $4.1 \pm 0.9$ & $4.4 \pm 0.1$ \\
\hline
\end{tabular}

Weight estimates ( \pm SE) include weight of fouling organisms which were most abundant in August (see Table 3 and Fig. 3). 'Whole' were cut at the stipe, 'Partial 1' were partially cut in May and 'Partial 2' were cut late June/early July. Yield estimates in bold indicate when kelp blades were partially cut. Sandsound partially cut harvest in August was sampled but not harvested, thus not applicable (NA) has been added

\section{Growth rates of annual and biannual harvests}

At the time of their deployment, the flask-cultivated sporophytes ranged from 1 to $10 \mathrm{~cm}$ in length, while the directly settled sporophytes were $<1 \mathrm{~cm}$ long but appeared to have a denser and more even distribution across the culture string spools. Following growth at sea, we did not find any noticeable difference in the performance between kelp produced by either of our two hatchery cultivation methods (flask and direct). The two cultivation methods were therefore pooled. Densities at both sites varied between the seeded $L$. digitata and naturally settled $S$. latissima. Laminaria digitata ranged from 14 to 54 individuals per $15 \mathrm{~cm}$ sample at Sandsound and 0-47 individuals at Lea of Trondra; S. latissima ranged from 0 to 23 individuals at Sandsound and 7-73 individuals at Lea of Trondra.

At the start of April, both kelp species had similar average lengths but between April and August $S$. latissima exhibited greater increase in length than $L$. digitata reaching a greater length on average (Fig. 1). Between the start and end of August, both species underwent a net loss in length at Lea of Trondra (Sandsound was only sampled once during August as the cultivated kelp was heavily deteriorated by biofouling). The longest individual of $L$. digitata was $64.9 \mathrm{~cm}$ recorded at Sandsound in July and the longest $S$. latissima was $110 \mathrm{~cm}$ recorded in August at Lea of Trondra. Both whole L. digitata and S. latissima significantly increased in length; however, only $S$. latissima significantly increased in width (Table 2).

Partially cut $L$. digitata did not significantly increase in length (Table 2). Both groups of partially cut S. latissima significantly regrew (Table 2). The rates of increase for blades partially cut in May (Partial 1) was similar to whole plants but slower for blades partially cut in June/July based on the slopes between data points (Fig. 2). Interestingly, in August, whole plants had a net loss in length of $2 \mathrm{~cm}$ on average while the partially cut plants had a net increase in length by approximately $10 \mathrm{~cm}$ on average. Saccharina latissima partially cut in June/July regrew but at slower rates to the earlier partial cutting treatment. Site was not a significant factor for length in either kelp species.

Average widths for L. digitata and S. latissima were broadly similar for each species across the growing season, sites and treatments (Fig. 2). L. digitata width ranged between 5 and $10 \mathrm{~cm}$ and did not significantly increase with time (Table 2). S. latissima width ranged from 3 to $10 \mathrm{~cm}$ and both whole and partially cut blades significantly increased in width over time (Table 2).

\section{Biomass yields of harvested kelp}

Wet weight estimates were not separated into kelp species as $L$. digitata and $S$. latissima grew mixed on the longlines. Variation between wet biomass yield estimates was evident between and within estimates based on $15 \mathrm{~cm}$ samples and 2-10 m harvests (Table 1). The average yield increased each month between March and August from less than $1 \mathrm{~kg} \mathrm{~m}^{-1}$ to $11-15 \mathrm{~kg} \mathrm{~m}^{-1}$ in August at both sites. However, despite the heaviest yields being achieved in August, the harvested kelp was severely degraded by fouling of tunicates making up large proportions of the wet weight (Table 3). Consequently, biomass yield estimates in August are confounded by the added weight of biofouling organisms; therefore, low confidence should be given to these estimates. The highest biomass yields achieved prior to heavy fouling were in late June/early July ranging from around 3 to $4 \mathrm{~kg} \mathrm{~m}^{-1}$ (Table 1). 
Table 2 Results of one- and two-way ANOVAs examining the effects of sampling time ${ }^{\mathrm{a}}$ and site on changes in length and width in L. digitata and S. latissima. Significant values are highlighted in bold.

\begin{tabular}{|c|c|c|c|c|c|c|}
\hline Response variable & Treatment & Factor & MS & $d f$ & $F$ & $p$ \\
\hline \multicolumn{7}{|l|}{ Laminaria digitata } \\
\hline \multirow[t]{6}{*}{ Length } & Whole & Time & 536.28 & 1 & 28.14 & $<0.001$ \\
\hline & & Error & 19.05 & 39 & & \\
\hline & Partial 1 & Time & 13.66 & 1 & 3.41 & 0.084 \\
\hline & & Error & 4.00 & 15 & & \\
\hline & Partial 2 & Time & 10.24 & 1 & 1.98 & 0.189 \\
\hline & & Error & 5.16 & 10 & & \\
\hline \multirow[t]{7}{*}{ Width } & Whole $^{\mathrm{b}}$ & Time & 7.12 & 1 & 1.89 & 0.178 \\
\hline & & Error & 3.78 & 38 & & \\
\hline & Partial $1^{\mathrm{c}}$ & Time & 1.29 & 1 & 1.24 & 0.285 \\
\hline & & Site & 8.75 & 1 & 8.37 & $<0.05$ \\
\hline & & Error & 1.05 & 14 & & \\
\hline & Partial 2 & Time & 0.04 & 1 & 0.01 & 0.915 \\
\hline & & Error & 2.98 & 10 & & \\
\hline \multicolumn{7}{|l|}{ Saccharina latissima } \\
\hline \multirow[t]{6}{*}{ Length } & Whole & Time & 2103.40 & 1 & 33.45 & $<0.001$ \\
\hline & & Error & 62.88 & 37 & & \\
\hline & Partial 1 & Time & 611.22 & 1 & 24.59 & $<0.001$ \\
\hline & & Error & 24.86 & 11 & & \\
\hline & Partial 2 & Time & 171.34 & 1 & 16.36 & $<0.01$ \\
\hline & & Error & 10.5 & 8 & & \\
\hline \multirow[t]{7}{*}{ Width } & Whole & Time & 113.18 & 1 & 51.25 & $<0.001$ \\
\hline & & Error & 2.21 & 37 & & \\
\hline & Partial 1 & Time & 18.17 & 1 & 7.28 & $<0.05$ \\
\hline & & Error & 2.49 & 11 & & \\
\hline & Partial $2^{c}$ & Time & 15.25 & 1 & 23.40 & $<0.01$ \\
\hline & & Site & 5.30 & 1 & 8.14 & $<0.05$ \\
\hline & & Error & 5.21 & 8 & 0.65 & \\
\hline
\end{tabular}

Site is only included when a significant factor. 'Whole' were cut at the stipe, 'Partial 1' were partially cut in May and 'Partial 2' were cut late June/early July. Includes mean squares (MS), degrees of freedom $(d f), F$ statistic $(F)$ and $p$ value $(p)$. Error is the residual error

${ }^{a}$ Sampling times were made by combining the two nearest sampling dates (maximum 8 days apart) as follows Mar/Apr $=1$, May $=2$, Jun/ $\mathrm{Jul}=3$, Aug $=4$, late Aug $=5$

${ }^{\mathrm{b}}$ Removed one large outlier

${ }^{\mathrm{c}}$ Note site is significant

\section{Biofouling on $L$. digitata and S. latissima}

The three types of biofouling organisms (epiphytes, tunicates and bryozoans; Fig. 1) were monitored monthly at both sites. Overall, $L$. digitata had a greater percentage blade area covered by fouling organisms than S. latissima (Fig. 3). While biofouling did occur on $S$. latissima, the mean blade cover was close to $0 \%$, with bryozoans making up the highest cover up to $5 \%$.
Epiphytes were primarily brown filamentous algae (e.g. Ectocarpus spp.) located on the distal tips of the L. digitata blade covering $<1 \%$ at Lea of Trondra of the blade area in May (Fig. 3a). The colonial organisms, tunicates and bryozoans, spread rapidly to high levels of cover in August on L. digitata (Fig. 3a). Similar ranges of percentage blade area fouled were recorded at both sites; at Sandsound, mid-August tunicates covered around between 1 and $8 \%$ and bryozoans between 15 and 35\%. At Lea of Trondra, rapid increases were seen at the start of August from 1\% cover of tunicates to $6 \%$ and from 5 to $40 \%$ of bryozoans on L. digitata (Fig. 3a). The tunicate Ciona intestinalis (Linnaeus) and the bryozoan Membranipora membranacea (Linnaeus) were commonly observed. While bryozoans encrusted a large area, they made up a thin sheet; on the other hand, tunicates were thick and heavy making up a large proportion of the wet weight (Table 3).

The total blade area indicates the blade growth and the area available for settlement of biofouling organisms (Fig. 4). Total blade area for $L$. digitata ranged between 2000 and $8000 \mathrm{~cm}^{2}$ at both sites and was greatest between May and July with a slight decrease towards late summer (Fig. 4a). S. latissima increased in total blade area from $3000 \mathrm{~cm}^{2}$ in April to $12,000 \mathrm{~cm}^{2}$ in the start of August, with one outlier just under $20,000 \mathrm{~cm}^{2}$ at Lea of Trondra decreasing slightly by the end of August (Fig. 4b). However, at Sandsound, total blade area of S. latissima remained below $3000 \mathrm{~cm}^{2}$ between March and August Sandsound (Fig. 4b). The fact S. latissima was not seeded but settled naturally is an important consideration when evaluating the differences between sites.

\section{Discussion}

The pattern, observed in the present study, of rapid growth in spring followed by degradation in late summer, due to blade breakage and biofouling, is well documented in natural and farmed kelp populations (Parke 1948; Kain 1979; Bartsch et al. 2008; Saunders and Metaxas 2008; Andersen et al. 2011; Zhang et al. 2012; Nielsen et al. 2014; Marinho et al. 2015; Freitas et al. 2016; Kregting et al. 2016). After 1 year's growth, S. latissima increased in length more than $L$. digitata and reached an average length of $40 \mathrm{~cm}$ with some individuals exceeding $1 \mathrm{~m}$, while $L$. digitata reached an average length of $30 \mathrm{~cm}$ and a maximum length of $65 \mathrm{~cm}$. In comparison, Edwards et al. (2011) achieved $L$. digitata lengths ranging from 40 to $100 \mathrm{~cm}$ in Ireland in June and S. latissima lengths of 80 to $150 \mathrm{~cm}$ on average. In Norway, average lengths of S. latissima peaked at 60-80 cm in June (Handå et al. 2013); in Denmark, average lengths reached $50 \mathrm{~cm}$ in June (Marinho et al. 2015); and in Spain, transplanted S. latissima grew to on average $120 \mathrm{~cm}$ long (Peteiro and Freire 2014). Large natural variation in growth is evident across and within studies varying across time, space, species, age and cultivation methods. In general, 
Fig. 2 Seasonal variation in average blade length and width (vertical bars are \pm SE) of Laminaria digitata and Saccharina latissima for whole and partially cut plants between March and August 2015 in the Shetland Islands. 'Whole' were cut at the stipe, 'Partial 1' were partially cut in May and 'Partial 2' were cut late June/early July

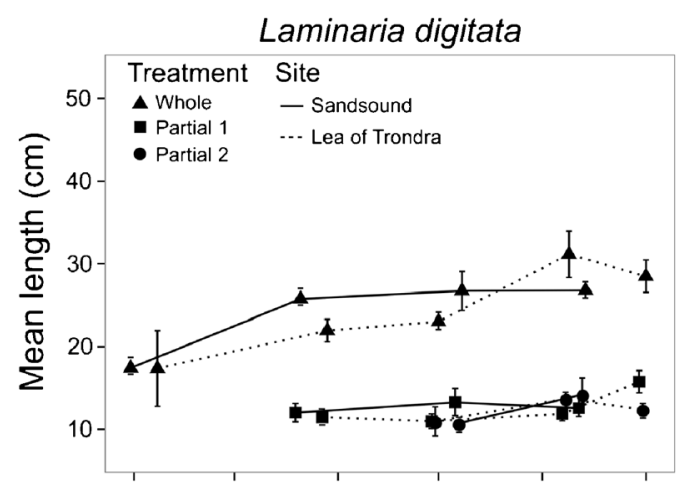

Saccharina latissima

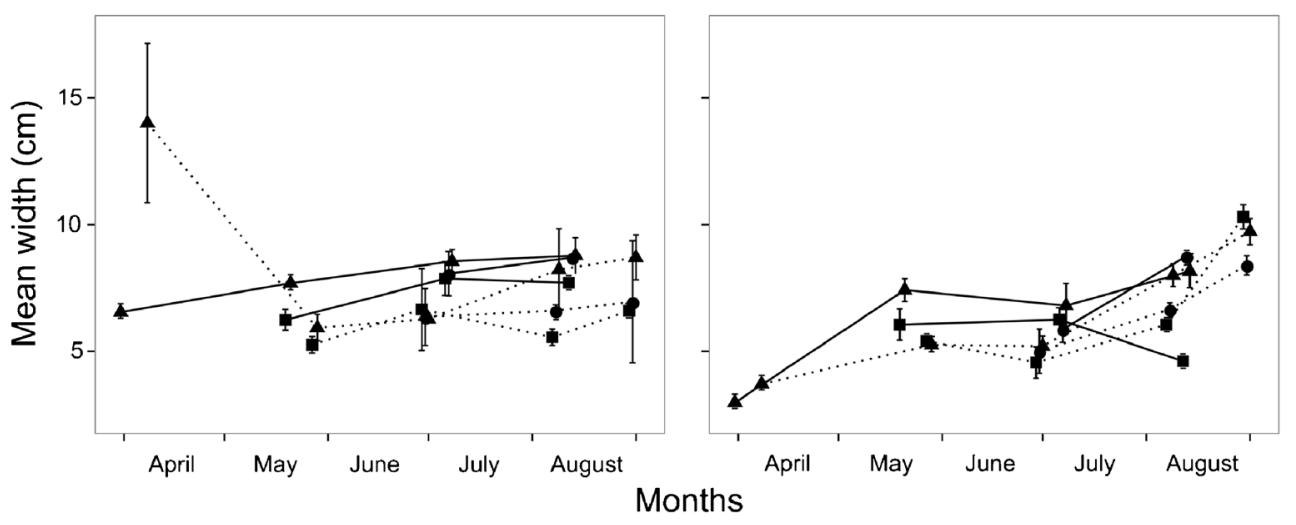

earlier deployment led to larger plants and greater biomass yields (Edwards et al. 2011; Handå et al. 2013). Sampling design is likely to lead to differences between studies making direct comparisons difficult; for example, in the present study, the mean length was calculated from all blades $>10 \mathrm{~cm}$ long while some other studies only use the ten largest blades.

The optimal harvesting period was May to early July prior to heavy biofouling with average biomass yields of combined L. digitata and $S$. latissima ranging from 2 to $4 \mathrm{~kg} \mathrm{~m}^{-1}$ fresh weight. In Ireland, yields ranged from 2 to $7 \mathrm{~kg} \mathrm{~m}^{-1}$ for L. digitata and 5.5 to $19 \mathrm{~kg} \mathrm{~m}^{-1}$ for S. latissima (Edwards et al. 2011); in Denmark, yields were $1 \mathrm{~kg} \mathrm{~m}^{-1}$ but increased to $3 \mathrm{~kg} \mathrm{~m}^{-1}$ after another year growth at sea (Marinho et al. 2015); and in Spain, average yields were $7.8 \mathrm{~kg} \mathrm{~m}^{-1}$ (Peteiro and Freire 2014). S. latissima has a naturally higher growth rate, achieving greater lengths and biomass yields than L. digitata (Edwards et al. 2011; Kerrison et al. 2015). Biomass yields vary, both due to natural variation across species, environments and cultivation methods, but are also further complicated by a lack of standard monitoring approach or inaccuracy, for example, when extrapolating yields from $15 \mathrm{~cm}$ sample lengths of longline (Table 1; Edwards et al. 2011).

The partially cut $S$. latissima regrew after being cut around $10 \mathrm{~cm}$ above the base of the blade, while $L$. digitata did not appear to regrow, showing neither an increase in length nor width. S. latissima increased around $10-15 \mathrm{~cm}$ in length between July and August for most harvest treatments. Interestingly, when a net loss was observed in August for $S$. latissima, the partially cut plants continued to grow increasing by roughly $30 \%$ between early and late August. This would suggest the meristem remains active, but that the rate of tissue loss in large plants is higher than the rate of growth. Two main effects on elongation rate can be hypothesised to occur after cropping. First of all, the rate of loss may be reduced as larger plants are correlated with greater rates of loss (Zhang et al. 2012). Secondly, growth is a result of active photosynthesis across the blade and therefore related to the size of the total blade area (Schmitz and Lobban 1976; Bartsch et al. 2008).
Table 3 Percentage wet weight of kelp harvested made up of tunicates

\begin{tabular}{|c|c|c|c|c|c|}
\hline \multirow[t]{2}{*}{ Site } & \multirow[t]{2}{*}{ Sampling date } & \multicolumn{2}{|l|}{ Whole cutting } & \multicolumn{2}{|l|}{ Partial cutting } \\
\hline & & $\begin{array}{l}\% \text { tunicates of } \\
\text { wet weight }\end{array}$ & $n$ & $\begin{array}{l}\% \text { tunicates of } \\
\text { wet weight }\end{array}$ & $n$ \\
\hline Sandsound & 13.08 .15 & $26.6 \pm 7.1$ & 5 & $36.5 \pm 3.9$ & 6 \\
\hline Lea of Trondra & 31.08 .15 & $12.4 \pm 6.2$ & 4 & $8.7 \pm 4.4$ & 4 \\
\hline
\end{tabular}


Fig. 3 Percentage blade area of Laminaria digitata (a) and Saccharina latissima (b) covered by epiphytes, tunicates and bryozoans at two sites: Lea of Trondra (white fill) and Sandsound (grey fill) between March and August 2015. The box plot has a median (horizontal line), upper and lower quantiles (box), an interquartile range $\pm 1.5 \times \mathrm{IQR}$ (vertical lines) and outliers (points). Please note $y$ axis scales are larger for bryozoans

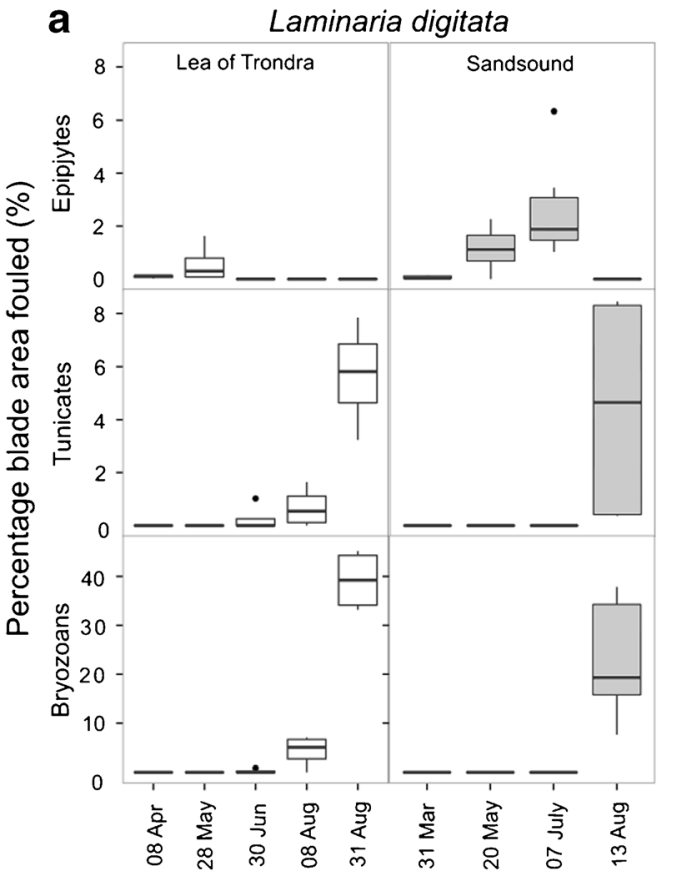

b Saccharina latissima

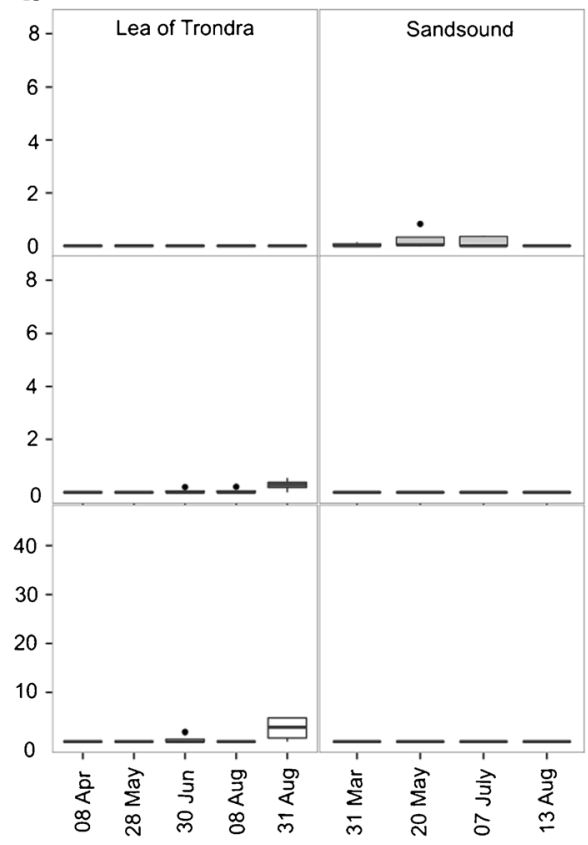

Fig. 4 Total blade area $\left(\mathrm{cm}^{2}\right)$ based on one side of a blade of Laminaria digitata (a) and Saccharina latissima (b) at two sites: Lea of Trondra (white fill) and Sandsound ( $g r e y$ fill) between March and August 2015. The box plot has a median (horizontal line), upper and lower quantiles (box), an interquartile range $\pm 1.5 \times$ IQR (vertical lines) and outliers (points)
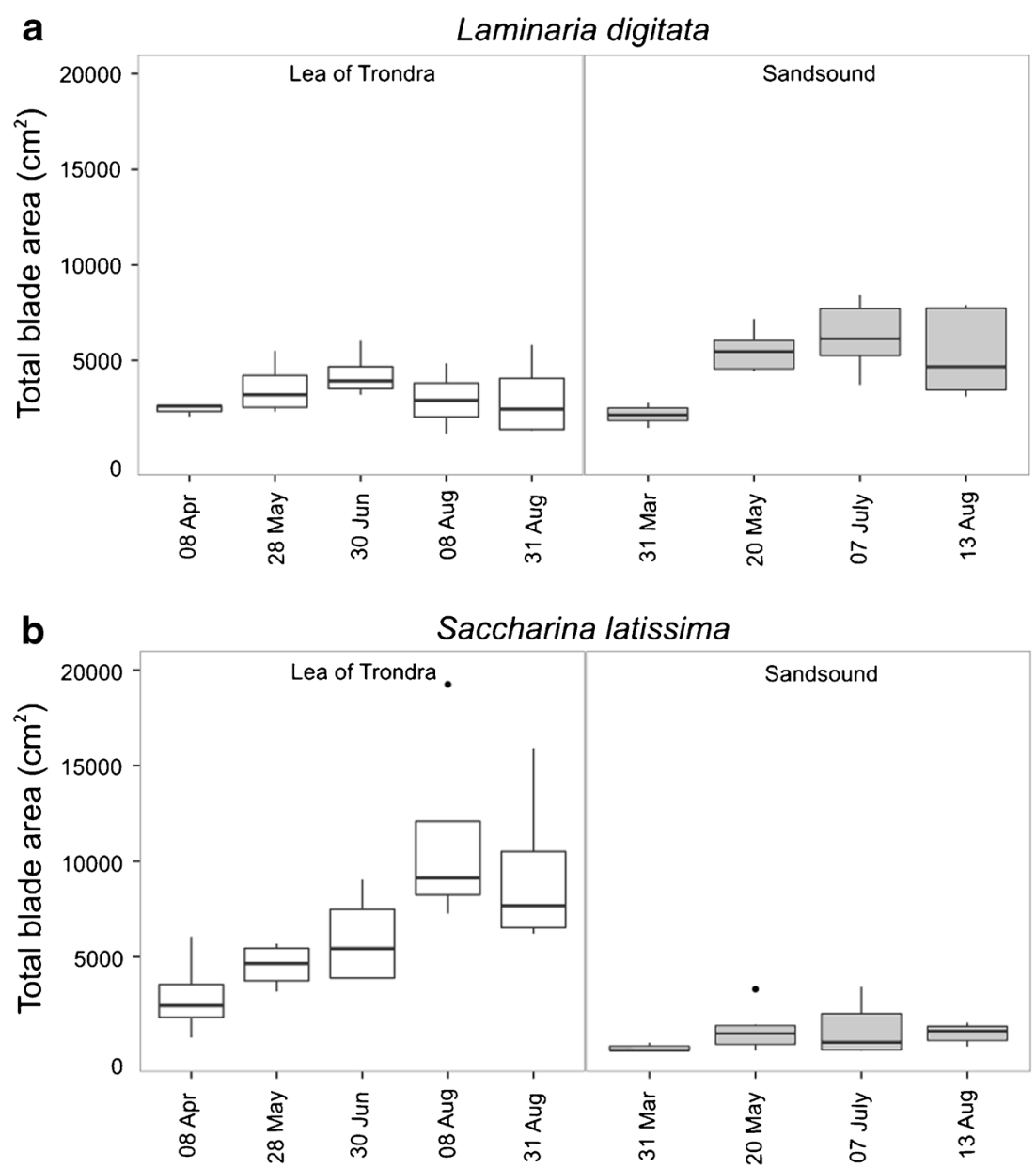
Consequently, removal of the blade $>10 \mathrm{~cm}$ severely reduces the area available for photosynthesis, potentially reducing the subsequent rate of growth. Furthermore, partially cutting kelp on a large scale across the longlines meant the cutting distance was approximate, meaning some blades were longer or shorter than the average $10 \mathrm{~cm}$ after partial cutting, which could have led to some variation in individual growth rates.

Improving the yield is dependent on the relative contribution of these two factors, a benefit is only achieved if the rate of erosion is reduced more than the rate of growth. Due to limitations in the experimental design, we were not able to separate the relative contributions of these effects on blade length in the present study. According to our findings, S. latissima appears a better candidate for partial cutting than $L$. digitata due to higher regrowth rates. However, based on a production cycle with partial cutting in May and final harvest in August, it is unclear whether this would improve the overall biomass yield compared to a single annual harvest. The higher yield would need to offset the cost of a second harvest; furthermore, the weight estimates were confounded by heavy biofouling and the combination of both kelp species. In comparison, E. maxima cut 10-30 $\mathrm{cm}$ above the base of the blade and harvested every 4 months improved yields by an estimated four to five times (Levitt et al. 2002). More recent reports from the Faroe Islands indicate both $S$. latissima and A. esculenta on longlines successfully regrew after partial harvesting using a similar production cycle as presented in this study (Bak et al. 2016).

Other approaches to improving yields have also been investigated. Harvesting biennially after two seasons of growth has, in some instances, improved biomass yields (Marinho et al. 2015) while others found a reduction in biomass but an increase in blade quality (Peteiro and Freire 2006). Thinning improved individual growth rates of rope-grown U. pinnatifida (Gao et al. 2014). Similarly, it was thought that harvesting the canopy plants in kelp forests facilitated kelp forest recovery by improving growth rates of sub-canopy recruits due to increased light availability (Christie et al. 1998; Levitt et al. 2002). However, when the hypothesis was tested, no effect on the growth of sub-canopy plants was observed, regardless of harvesting method (whole or partial cutting) (Anderson et al. 2006). Whether harvesting wild or farmed plants, improving yields of kelp relies on an understanding of their biology and ecology. In order to optimise kelp production, the mechanisms controlling growth in seaweed need to be elucidated, in particular the effect of blade size and density on individual growth rates in farmed seaweed and how local and regional environmental factors influence growth.

Biofouling is a natural phenomenon affecting wild kelp populations (Saunders and Metaxas 2008; Andersen et al. 2011). However, in farmed kelp, the effects of fouling organisms limit the harvest season due to a reduction in biomass and quality, making the kelp unsuitable for human consumption. Interestingly, at our sites in the Shetland Islands, L. digitata was more severely affected by biofouling than S. latissima. It could be hypothesised that the lamina of $L$. digitata may provide a better substrate for settlement and growth of fouling organisms. Alternatively, the generally thicker lamina may suffer reduced breakage under the weight of fouling organisms. However, farmed S. latissima has been documented to become heavily fouled by bryozoans in Norway and Denmark with an average cover of $80 \%$ by August (Marinho et al. 2015; Førde et al. 2016). Consequently, we cannot assume that $S$. latissima is always less fouled than $L$. digitata. We consider it more likely that the environmental conditions at the two sites were not optimal for L. digitata - as it is normally found in more exposed areas than $S$. latissima. Species-specific requirements are therefore a very important consideration when choosing sea cultivation sites (Kerrison et al. 2015).

Increased exposure is linked to reduced levels of biofouling (Andersen et al. 2011; Peteiro and Freire 2013). The kelp farming sites used in the present study were located in sounds along the west coast of Shetland, sheltered from the Atlantic Ocean by outcrops of land, but with high water exchange and moderate exposure due to the strong wind, waves and tides. Very few $L$. digitata individuals became digitated, possibly suggesting environmental factors (e.g. water motion) at the two study sites were not optimal for full development. Growing $L$. digitata at more exposed sites in Shetland may improve growth and reduce fouling. Moving to more exposed sites presents other challenges; severe storms affect Shetland in the winter and can break and displace aquaculture structures and lead to loss of kelp biomass.

Epiphytes were present on $L$. digitata until July and primarily attached to the distal part of the blades. Generally, biofouling organisms appear to settle on the distal tips of the kelp first (Park and Hwang 2012; Peteiro and Freire 2013; Førde et al. 2016). The disappearance of epiphytes from the kelp coincided with a reduction in kelp blade length and is therefore likely to be a result of erosion.

In the present study, fouling by colonial tunicates and bryozoans severely deteriorated the kelp in July/August, later than the epiphytes. The underlying causes were not investigated; however, many studies have suggested that the rapid growth of these colonial organisms occurs after a rise in sea temperature (Saunders and Metaxas 2008; Ramsay et al. 2009; Park and Hwang 2012; Peteiro and Freire 2013; Freitas et al. 2016). Consequently, the onset of biofouling occurs earlier at lower latitudes. In Spain, severe biofouling takes hold by April (Peteiro and Freire 2013; Freitas et al. 2016), in Ireland by June (Edwards et al. 2011) and in Norway by July (Handå et al. 2013; Førde et al. 2016). In Korea, earlier onset of biofouling hydroids has led to the harvest season ending in May instead of July, which Park and Hwang (2012) attributed to higher sea temperatures. In Nova Scotia, field and laboratory studies have shown that higher temperatures, along with food availability, led to earlier and larger fouling colonies of the bryozoan M. membranacea (Saunders and Metaxas 2008, 
2009; Scheibling and Gagnon 2009). In Prince Edward Island (Canada), the cover and weight of $C$. intestinalis increased rapidly in mid-July and recruitment increased with temperature (Ramsay et al. 2009) similar to the findings in the present study. Tunicates made up a larger proportion of the wet weight in August at Sandsound than at Lea of Trondra, 26-37\% and 8$12 \%$, respectively. Coincidentally, SSTs in July and August were $2{ }^{\circ} \mathrm{C}$ higher at Sandsound (Table 1), and the following year (2016), an earlier onset of fouling was observed along with higher sea temperatures (unpublished data). It is, however, important to note that Sandsound also had a higher proportion of the more heavily fouled $L$. digitata than Lea of Trondra.

Bryozoans covered a larger area but the settlement of tunicates, most predominantly $C$. intestinalis, made up a larger volume and caused the greatest deterioration in blade quality. Other studies have reported bryozoans as the primary biofouling problem (Handå et al. 2013; Marinho et al. 2015; Førde et al. 2016); however, it is a major problem in mussel farms where $C$. intestinalis reduces mussel production (Howes et al. 2007). The settling larvae of $C$. intestinalis preferentially settle on shaded substrates at shallow depths (Howes et al. 2007), making the ropes and kelp blades on a seaweed farm an optimal settlement substrate. Based on biomass yields and the onset of biofouling in 2015, the optimum harvest time in Shetland was around May to early July. However, optimum harvest times are expected to vary from year to year dependent on the timing of biofouling, most likely determined by environmental factors such as temperature.

Low sample size of independent replicates and number of sites were the main limitations of the study. However, the number of technical replicates within each sample was on average 50 individuals which were then further subdivided into kelp species. It is important to note that, due to natural settlement of $S$. latissima, population sizes of the two kelp species were not equal, varied between sites and meant biomass estimates could not be separated for each kelp species. $L$. digitata growth may have been limited due to high density of S. latissima settlement. Total blade area varied more between sites for $S$. latissima than L. digitata, which is most likely due to the fact $S$. latissima settled naturally and is therefore more dependent on natural supply and factors influencing settlement.

Overall, using image analysis was an effective approach to monitoring growth and biofouling. The method allowed larger numbers of fresh specimens to be sampled/photographed as all measurements were taken post-sampling. However, while species of kelp were easily distinguished in pictures, biofouling organisms were divided into much broader groups. Similarly, the image analysis was limited to two-dimensional measurements and consequently did not take into account threedimensional differences, such as differences in lamina thickness and the volume of the biofouling organisms. Standardisation of sampling methods for seaweed farming is currently lacking and would facilitate comparison between studies.
To conclude, a marked difference in regrowth rates and biofouling blade coverage was observed between $L$. digitata and S. latissima. However, knowledge regarding the factors controlling growth and biofouling in both kelp is severely limited. Based on the findings in the present study, S. latissima is a candidate for regrowth and multiple harvests within a single growing season. However, biofouling occurring in late summer limits the period for growth. Biofouling is a problem globally, and while the onset of biofouling shows some latitudinal trends linked to temperature, local variation between sites could be more important than large-scale effects. Species-specific site selection is needed to optimise kelp biomass yields. Therefore, future studies need to understand how environmental conditions such as temperature and exposure affect growth and biofouling of different species of cultivated kelp.

Acknowledgements The research was conducted as part of the Shetland Seaweed Growers project funded by the Coastal Communities Fund (delivered by Big Lottery Fund on behalf of the UK Government and the devolved administrations in Northern Ireland, Scotland and Wales) which aims to encourage economic development of UK coastal communities by giving funding to create sustainable economic growth and jobs. The authors would like to thank the project partners Scottish Sea Farms Ltd for their generous contribution of a site as well as workboats and experienced staff to grow kelp at Sandsound, the NAFC Marine Centre for the provision of a hatchery facility and site, and our contractors East Voe Shellfish Ltd for their dedication, time and workboats. Finally, thanks are given to Daniel Cowing, Luke Batts and Paul MacDonald for their critical review of the manuscript and discussions.

\section{Compliance with ethical standards}

Disclosure of potential conflicts of interest The Shetland Seaweed Growers project was financed by the Coastal Communities Fund (Big Lottery Fund, UK Government) and received in-kind funding from Scottish Sea Farms Ltd and NAFC Marine Centre. C.R. and L.M. are partially funded by the MacroBioCrude research consortium (Engineering and Physical Sciences Research Council grant no. EP/ K014765/1). C.R. has received a grant for educational program from the Marine Alliance for Science and Technology for Scotland and financial support from the University of Highlands and Islands for attending the International Seaweed Symposium 2016.

Open Access This article is distributed under the terms of the Creative Commons Attribution 4.0 International License (http:// creativecommons.org/licenses/by/4.0/), which permits unrestricted use, distribution, and reproduction in any medium, provided you give appropriate credit to the original author(s) and the source, provide a link to the Creative Commons license, and indicate if changes were made.

\section{References}

Andersen GS, Steen H, Christie H, Fredriksen S, Moy FE (2011) Seasonal patterns of sporophyte growth, fertility, fouling, and mortality of 
Saccharina latissima in Skagerrak, Norway: implications for forest recovery. J Mar Biol 2011:690375. doi:10.1155/2011/690375

Anderson RJ, Rothman MD, Share A, Drummond H (2006) Harvesting of the kelp Ecklonia maxima in South Africa affects its three obligate, red algal epiphytes. J Appl Phycol 18:343-349

Bak U, Gregersen O, Mols-Mortensen A, Trond G (2016) Cost of commercial-scale offshore cultivation in the Faroe Islands using multiple partial cutting. Conference abstract from the 22nd International Seaweed Symposium 2016 June 19-24, Copenhagen Denmark

Bartsch I, Wiencke C, Bischof K, Buchholz CM, Buck BH, Eggert A, Feuerpfeil P, Hanelt D, Jacobsen S, Karez R, Karsten U, Molis M, Roleda MY, Schubert H, Schumann R, Valentin K, Weinberger F, Wiese J (2008) The genus Laminaria sensu lato: recent insights and developments. Eur J Phycol 43:1-86

Christie H, Fredriksen S, Rinde E (1998) Regrowth of kelp and colonization of epiphyte and fauna community after kelp trawling at the coast of Norway. Hydrobiologia 375(376):49-58

Edwards MD, Dring MJ (2011) Open-sea cultivation trial of the red alga, Palmaria palmata from seeded tetraspores in Strangford Lough, Northern Ireland. Aquaculture 317:203-209

Edwards M, Watson L, O'Mahony F, Connellan L, Dring M, Werner A (2011) Cultivating Laminaria digitata. Bord Iascaigh Mhara, Dun Laoaghaire, $\mathrm{p} 71$

Flavin K, Flavin N, Flahive W (2013) Kelp farming manual. A guide to the processes, techniques and equipment for farming kelp in New England waters. Ocean Approved $.130 \mathrm{pp}$. Retrieved from https:// static1.squarespace.com/static/52f23e95e4b0a96c7b53ad7c/t/ 52f78b0de4b0374e6a0a4da8/1391954701750/OceanApproved KelpManualLowRez.pdf on 14 July 2016

Førde H, Forbord S, Handå A, Fossberg J, Arff J, Johnsen G, Reitan KI (2016) Development of bryozoan fouling on cultivated kelp (Saccharina latissima) in Norway. J Appl Phycol 28:1225-1234

Freitas JRC, Morrondo JMS, Ugarte JC (2016) Saccharina latissima (Laminariales, Ochrophyta) farming in an industrial IMTA system in Galicia (Spain). J Appl Phycol 28:377-385

Gao X, Endo H, Taniguchi K, Agatsuma Y (2014) Effects of experimental thinning on the growth and maturation of the brown alga Undaria pinnatifida (Laminariales; Phaeophyta) cultivated in Matsushima Bay, northern Japan. J Appl Phycol 26:529-535

Guiry MD, Morrison L (2013) The sustainable harvesting of Ascophyllum nodosum (Fucaceae, Phaephyceae) in Ireland, with notes on the collection and use of some other brown algae. J Appl Phycol 25:1823-1830

Handå A, Forbord S, Wang X, Broch OJ, Dahle SW, Størseth TR, Reitan KI, Olsen Y, Skjermo J (2013) Seasonal- and depth-dependent growth of cultivated kelp (Saccharina latissima) in close proximity to salmon (Salmo salar) aquaculture in Norway. Aquaculture 414:191-201

Henley WJ, Dunton KH (1995) A seasonal comparison of carbon, nitrogen and pigment content in Laminaria solidungula and L. saccharina (Phaeophyta) in the Alaskan. J Phycol 31:325-331

Howes S, Herbinger CM, Darnell P, Vercaemer B (2007) Spatial and temporal recruitment of the tunicate Ciona intestinalis on a mussel farm in Nova Scotia, Canada. J Exp Mar Bio Ecol 342:85-92

Kain JM (1979) A view of the genus Laminaria. Oceanogr Mar Biol Ann Rev 17:101-161

Kerrison PD, Stanley MS, Edwards M, Black KD, Hughes AD (2015) The cultivation of European kelp for bioenergy: site and species selection. Biomass Bioenergy 80:229-242

Kraan S (2013) Mass-cultivation of carbohydrate rich macroalgae, a possible solution for sustainable biofuel production. Mitig Adapt Strateg Glob Change 18:27-46

Kregting L, Blight AJ, Elsäßer B, Savidge G (2016) The influence of water motion on the growth rate of the kelp Laminaria digitata. J Exp Mar Biol Ecol 478:86-95
Krumhansl KA, Scheibling RE (2011) Detrital production in Nova Scotian kelp beds: patterns and processes. Mar Ecol Prog Ser 421:67-82

Levitt GJ, Anderson RJ, Boothroyd CJT, Kemp FA (2002) The effects of kelp harvesting on its regrowth and the understorey benthic community at Danger Point, South Africa, and a new method of harvesting kelp fronds. S Afr J Mar Sci 24:71-85

Lewin J (1966) Silicon metabolism in diatoms. V. Germanium dioxide, a specific inhibitor of diatom growth. Phycologia 6:1-12

Marinho GS, Holdt SL, Birkeland MJ, Angelidako I (2015) Commercial cultivation and bioremediation potential of sugar kelp, Saccharina latissima, in Danish waters. J Appl Phycol 27:1963-1973

McLaughlin E, Kelly J, Birkett D, Maggs C, Dring M (2006) Assessment of the effects of commercial seaweed harvesting on intertidal and subtidal ecology in Northern Ireland. Environment and Heritage Service Research and Development Series. No. 06/26, pp 90

Nielsen MM, Krause-Jensen D, Olesen B, Thinggaard R, Christensen PB, Bruhn A (2014) Growth dynamics of Saccharina latissima (Laminariales, Phaeophyceae) in Aarhus Bay, Denmark, and along the species' distribution range. Mar Biol 161:2011-2022

Park CS, Hwang EK (2012) Seasonality of epiphytic development of the hydroid Obelia geniculata on cultivated Saccharina japonica (Laminariaceae, Phaeophyta) in Korea. J Appl Phycol 24:433-439

Parke M (1948) Studies on the British Laminariaceae. I. Growth in Laminaria saccharina (L.) Lamour. J Mar Biol Ass UK 27:651-709

Peteiro C, Freire Ó (2006) Cultivation of the autoctonous seaweed Laminaria saccharina off the Galician coast (NW Spain): production and features of the sporophytes for an annual and biennial harvest. Thalassas 22:45-53

Peteiro C, Freire Ó (2013) Epiphytism on blades of the edible kelps Undaria pinnatifida and Saccharina latissima farmed under different abiotic conditions. J World Aquacult Soc 44:706-715

Peteiro C, Freire Ó (2014) Open-sea cultivation by transplanting young fronds of the kelp of Saccharina latissima. J Appl Phycol 26:519-528

R Core Team (2013) R: a language and environment for statistical computing. R foundation for statistical computing, Vienna, Austria (ISBN 3-900051-07-0, https://R-project.org/)

Ramsay A, Davidson J, Bourque D, Stryhn H (2009) Recruitment patterns and population development of the invasive ascidian Ciona intestinalis in Prince Edward Island, Canada. Aquat Invasions 4:169-176

Redmond S, Green L, Yarish C, Kim J, Neefus C (2014) New England seaweed culture handbook - nursery systems. Connecticut Sea Grant CTSG-14-01. 92 pp. Retrieved from https://seagrant.uconn. edu/publications/aquaculture/handbook.pdf on 9 August 2016

RStudio (2012) RStudio: integrated development environment for R, 098501 st edn. RStudio, Boston

Saunders M, Metaxas A (2008) High recruitment of the introduced bryozoan Membranipora membranacea is associated with kelp bed defoliation in Nova Scotia, Canada. Mar Ecol Prog Ser 369:139-151

Saunders M, Metaxas A (2009) Population dynamics of a nonindigenous epiphytic bryozoan Membranipora membranacea in the western North Atlantic: effects of kelp substrate. Aquat Biol 8:83-94

Scheibling RE, Gagnon P (2009) Temperature-mediated outbreak dynamics of the invasive bryozoans Membranipora membranacea in Nova Scotian kelp beds. Mar Ecol Prog Ser 390:1-13

Schmitz K, Lobban CS (1976) A survey of translocation in Laminariales (Phaeophyceae). Mar Biol 36:207-216

Vea J, Ask E (2011) Creating a sustainable commercial harvest of Laminaria hyperborea, in Norway. J Appl Phycol 23:489-494

Wickham H (2009) ggplot2: elegant graphics for data analysis. Springer, Berlin, p 224

Zhang J, Fang J, Wang W, Du M, Gao Y, Zhang M (2012) Growth and loss of mariculture kelp Saccharina japonica in Sungo Bay, China. J Appl Phycol 24:1209-1216 